\title{
Pengembangan Komik Sebagai Media Pemeblajaran Ilmu Pengetahuan Sosial (IPS) Kelas IV SDN 2 Selong
}

\author{
Yul Alfian Hadi ${ }^{1}$, Muhammaad Husni ${ }^{2}$, Rodiatul Pazri ${ }^{3}$ \\ Program Studi Pendidikan Guru Sekolah Dasar ${ }^{1,2,3}$ \\ yulalfianhadi@yahoo.com ${ }^{1}$, muhammad.husni2014@gmail.com ${ }^{2}$, \\ rodiatulpazri22@gmail.com ${ }^{3}$
}

Penelitian ini bertujuan untuk mengembangkan produk berupa media pembelajaran yang layak digunakan dalam proses pembelajaran. Metode Penelitian yang digunakan dalam penelitian ini yaitu metode penelitian dan pengembangan (Reasearch and Development) dengan mengadopsi model $4 \mathrm{D}$, yang kemudian disederhanakan menjadi tiga tahap karena keterbatasan pengembangan. Subjek penelitian ini adalah siswa kelas IV SDN 2 Selong yang berjumlah 30 siswa. Teknik pengumpulan data menggunakan lembar instrument validasi ahli dan angket respon siswa. Hasil penelitian ini menunjukkan bahwa hasil validasi pertama oleh ahli desain diperoleh skor 47 yang berada pada rentang skor $39<\mathrm{X} \leq 51$, dengan kategori "Cukup", hasil validasi ke dua oleh ahli desain diperoleh skor 57, yang terdapat pada rentang skor $51<\mathrm{X} 63$, dengan kategori "Baik", hasil validasi ahli materi memperoleh skor 60, yang berada pada rentang skor $51<\mathrm{X} 63$, dengan kategori "Baik", hasil uji coba lapangan memperoleh rata-rata skor 42,13 yang berada pada rentang $X>42,06$, dengan kategori "Sangat Baik". Hal ini menunjukkan bahwa media komik layak digunakan sebagai media pembelajaran.

Kata Kunci: Komik, Reasearch and Development. 


\section{PENDAHULUAN}

Pendidikan adalah suatu usaha terencana untuk mewujudkan suasana belajar dan proses pembelajaran agar peserta didik mampu mengembangkan potensi yang ada pada dirinya. Dengan adanya pendidikan seseorang mampu menentukan yang terbaik untuk kehidupannya di masa yang akan datang, yang nantinya akan mempengaruhi kualitas suatu bangsa. Sebagai mana yang di amanatkan oleh Undang-Undang Sisdiknas No.20 Tahun 2003Ahmad Susanto (2014: 1)

Pendidikan berperan mengembangkan kemampuan dan membentuk watak serta peradaban bangsayang bermartabat dalam rangka mencerdaskan kehidupan bangsa, mengembangkan potensi anak agar menjadi manusia yang beriman, dan bertakwa kepada Tuhan Yang Maha Esa, berakhlak mulia, sehat, berilmu, cakap, mandiri, kreatif dan menjadi warga negara yang demokratis dan bertanggung jawab.

Untuk mencapai pendidikan yang berkualitas sesuai dengan amanat Sisdiknas, tidak terlepas dari peran guru didalamya. Guru berperan aktif dalam memberikan pendidikan yang berkualitas untuk peserta didiknya. Guru yang berkeinginan kuat serta tekun untuk meningkatkan kualitas peserta didiknya akan menggunakan segala cara untuk memberikan pemahaman kepada peserta didiknya dalam kegiatan belajar, baik itu dengan menggunakan startegi penyampaian materi yang beragam, maupun fasilitas yang menunjang pemahaman peserta didik dalam belajar.

Fasilitas yang dapat menunjang pemahaman peserta didik Salah satunya yaitu penggunaan media pembelajaran dalam proses pembelajaran. Gagne dalam Sadiman dkk (2012: 6) menyatakan bahwa media merupakan semua jenis komponen dalam lingkungan peserta didik yang dapat merangsangnya untuk belajar. Dengan digunakannya media pembelajaran dalam proses pemebalajaran peserta didik akan lebih antusias dalam belajar, apalagi media pembelajaran yang digunakan unik, sesuai dengan perkembangan zaman, dan tentunya mampu menarik perhatian siswa. Media pembelajaran yang lebih menekankan sisi visualnya, tentu akan menambah antusias peserta didik dalam belajar khususnya untuk peserta didik di Sekolah Dasar. Hal ini juga ditemukan pada siswa kelas IV SDN 2 Selong. Adapun salah satu media yang menekankan pada sisi visual adalah komik.

Komik adalah salah satu karya sastra anak yang menampilkan gambargambar, panel-panel (kotak) secara berderet yang disertai balon-balon teks tulisan 
yang membentuk suatu cerita Burhan Nurgiyantoro (2013: 409). Gambar-gambar dalam komik merupakan sebuah penangkapan adegan serta peristiwa yang disampaikan dengan menampilkan figure dan latar. Selain itu balon-balon teks yang ada didalam gambar memperkuat makna yang ingin disampaikan Komikus (pembuat komik).

Saat ini komik tidak hanya menjadi suatu media penghibur bagi peserta didik, namun komik juga dapat dijadikan sebagai media edukasi. Dengan membaca komik, peserta didik dapat meningkatkan daya imajinasi serta kreativitas khususnya bagi peserta didik yang belum bisa membaca. Sebagaimana yang di ungkapkan Seto Mulyadi seorang psikolog bahwa membaca komik dapat membantu memvisualisasikan imajinasi anak yang belum bisa membaca Nick Soedarsao (2015: 497). Apabila komik dijadikan sebagai media pembelajaran tentunya peserta didik akan lebih mudah memahami apa yang disampaikan oleh guru, selain itu juga peserta didik dapat terhindar dari kesalahan pemahaman. Khusunya pada mata pelajaran IPS yang lebih cenderung untuk mengingat, mengenali, dan menghubungkan fakta dan konsep yang bersifat abstrak. dan tidak jarang dalam proses pembelajarannya guru hanya mengguanakan metode menghafal dan ceramah. Proses belajar seperti ini akan menimbulkan rasa bosan dan kelelahan berfikir kepada peserta didik.

Ahmad Susanto (2015: 316) mengemukakan bahwa proses belajar dengan cara menghafal dapat menimbulkan beberapa masalah. Masalah yang ditimbulkan seperti kebosanan, kelelahan berfikir, serta menyulitkan peserta didik untuk memperluas wawasan, sehingga membuat pengetahuan peserta didik menjadi dangkal. Maka dari itu Susanto sangat menekankan kepada guru untuk memiliki kreatifitas dalam mengajarkan mata pelajaran IPS ini untuk peserta didik karena materi pembelajaran IPS sangat penting untuk di ajarkan serta dipahami oleh peserta didik.

Berdasarkan hasil wawancara dan observasi yang telah dilakukan peserta didik lebih tertarik belajar apabila materi yang disajikan lebih menekankan sisi visual, salah satunya yaitu menggunakan komik. Hal ini diketahui dari hasil wawancara peneliti terhadap beberapa orang siswa pada saat keluar bermain. Peneliti menanyakan alasan mengapa tidak bersemangat dalam belajar serta menanyakan apa yang mereka suakai misalnya buku apa saja. Karena pada saat observasi peneliti 
melihat beberapa peserta didik tidak bersemangat dalam belajar, sehingga mencari kesenangan lain seperti menganggu teman yang sedang belajar dan ada pula yang berbicara ketika guru sedang menjelaskan. Dari pertanyan tersebut peserta didik menjawab mereka merasa bosan pada saat pembelajaran berlangsung karena tidak ada yang memotivasi peserta didik untuk semangat dalam belajar. Serta buku yang mereka sukai dan sering di baca yaitu buku cerita bergambar dan komik.

\section{METODE PENELITIAN}

Pengembangan media ini menggunakan metode penelitian dan pengembangan (Reasearch and Development). Metode penelitian dan pengembangan (Reasearch and Development) adalah metode penelitian yang digunakan untuk menghasilkan produk tertentu dan menguji keefektifan produk tersebut (Sugiyono, 2016: 407). Penelitian ini mengadopsi model pengembangan Thiagarajan atau yang dikenal dengan 4D yang merupakan kepanjangan dari Define (pendefinisian), Design (perancangan), Development (Pengembangan), and Dissemination (penyebaran).

Tahap pendefinisian berisi kegiatan untuk menetapkan produk apa yang akan dikembangkan beserta spesifikasinya. Perencanaan berisi perancangan terhadap produk yang telah di tetapkan, sesuai dengan karakteristik siswa, pemilihan bentuk penyajian media pembelajaran. Pengembangan berisi kegiatan membuat rancangan menjadi produk dan menguji validitas produk.kemudian, produk diuji coba secara terbatas pada peserta didik untuk mengetahui kelayakannya. Penyebaran Berisi kegiatan menyebarluaskan produk yang telah teruji untuk dimanfaatkan orang lain.

Berdasar pada keterbatasan peneliti maka tahapan ini disederhanakan menjadi 3 tahapan yaitu: Pendefinisian (Define, Perancangan (Dsign), Pengembangan (Development). Subjek uji coba lapangan pada penelitian pengembangan media komik adalah peserta didik kelas IV SDN 2 Selong Tahun pelajaran 2019/2020, dengan jumlah 30 orang. Jenis data yang diperoleh dalam penelitian ini adalah data kualitatif dan kuantitatif. Data kualitaitif didapatkan dari data hasil respon ahli yaitu ahli media pada saat uji validasi dan hasil angket respon siswa. jenis data kualitaitif yang digunakan dalam penelitian ini adalah menggunakan lembar validasi tim ahli, yang berbentuk angket berupa ratting scale skala lima dengan kriteria sebagai berikut (5) sangat baik, (4) baik, (3) cukup, (2) kurang, (1) kurang sekali. Instrumen 
Pengumpulan Data yang digunakan pada penelitian ini adalah : Lembar Validasi Ahli Media, Lembar Validasi Ahli Materi dan Lembar Angket Respon Siswa.

Untuk menentukan dan mengetahui kualitas produk maka data kualitatif yang didapatkan dari uji ahli materi dan media melalui lembar validasi skala lima akan dikonversikan kedalam data kualitaif dengan metode konversi skala lima yang dikemukakan oleh Eko Putra Widyoko (2017: 238).

\section{Tabel 1 .}

konversi data kuantitatif ke data kualitatif dengan skala lima

\begin{tabular}{|c|c|c|}
\hline Nilai & Interval Skor & Kategori \\
\hline A & $\mathrm{X}>\bar{X}_{i}+1,8 \times s b_{i}$ & Sangat baik \\
\hline B & $\bar{X}_{i}+0,6 \times s b_{i}<\mathrm{X} \leq \bar{X}_{i}+1,8 \times s b_{i}$ & baik \\
\hline C & $\bar{X}_{i}-0,6 \times s b_{i}<\mathrm{X} \leq \bar{X}_{i}+0,6 \times s b_{i}$ & cukup \\
\hline D & $\bar{X}_{i}-1,8 \times s b_{i}<\mathrm{X} \leq \bar{X}_{i}-0,6 \times s b_{i}$ & kurang \\
\hline E & $\mathrm{X} \leq \bar{X}_{i}-1,8 \times s b_{i}$ & Sangat kurang \\
\hline
\end{tabular}

\section{HASIL DAN PEMBAHASAN}

\section{Hasil}

\section{Tahap Pendefinisian (Define)}

Pada tahap pendefinisian dilakukan beberapa tindakan seperti analisis kebutuhan, analisis peserta didik, analisis materi, serta merumuskan tujuan pembelajaran.

\section{Tahap Perancangan (Design)}

Adapun langkah-langkah yang dilakukan pada tahap ini sebagai berikut: 1) Pemilihan Media yaitu pengembangan media komik yang dirancang untuk membuat proses pembelajaran lebih menarik sehingga siswa semangat untuk belajar. 2) Pemilihan Format (Rancangan Awal) : Format awal media komik ini dibuat menggunakan Adobe Illustrator dan Adobe Photoshop. 3) Pembuatan Media Pebelajaran Berbentuk Komik, langkah pembuatan media komik yaitu: a) Pembuatan Naskah Skenario, b) Pembuatan ilustrasi, c) Pengisian balon teks, d) Penyusunan dan finishing.

\section{Pengambangan (Development)}

Validasi Produk Media Komik 
Rancangan awal atau prototype 1 yang telah di kembangkan dan divalidasi oleh kedua orang validator ahli yang merupakan dosen universitas hamzanwadi dan guru kelas IV SDN 2 Selong. tahap validasi dilakukan dengan memberikan penilaian pada lembar validasi terhadap media komik.

Data Uji Coba Media Komik

Uji coba ini dimaksudkan untuk melihat kelayakan media komik dalam pembelajaran. Hasil yang didapat kemudian dikonversikan kedalam data kualtatif skala lima dengan acuan rumus yang ada.

Hasil Validasi Ahli Media

Berdasarkan hasil validasi pertama yang telah dilakukan, pada tanggal 29 Juli 2019 diketahui bahwa penilaian produk dari ahli desain berada pada rentang skor $39<\mathrm{X} \leq 51$, dengan perolehan skor pada aspek tampilan 24 , pada aspek bahan memperoleht skor 10 dan pada aspek manfaat memperoleh skor 13. maka dapat diketahui jumlah total skor 47. sehingga produk berupa media komik berada pada kategori "CUKUP”. Hal ini menunjukkan bahwa media komik layak digunakan untuk mengambil data dengan revisi seseuai saran.

Setelah peneliti melakukan revisi sesuai saran, ahli desain melakukan validasi ke dua, berdasarkan hasil validasi ke dua oleh ahli desain maka dapat diketahui bahwa produk komik berada pada rentang skor $51<\mathrm{X} 63$ dengan perolehan skor pada aspek tampilan 32, pada aspek bahan memperoleht skor 12 dan pada aspek manfaat memperoleh skor 13. maka dapat diketahui total skor 57, yang berada pada kategori "BAIK".

Hasil Validasi Ahli Materi

Berdasarkan hasil validasi yang telah dilakukan pada tanggal 09 agustus, produk berupa media komik mendapat skor pada aspek penilian isi dengan jumlah skor 49 dan pada aspek bahasa dan tulisan mendapat skor 11 . maka dapat diketahui bahwa total skor untuk validasi ahli materi ini adalah 60 yang berada pada rentang skor $51<$ X 63 dengan kategori "BAIK". Hal ini menunjukkan bahwa media komik layak digunakan untuk mengambil data dengan revisi sesuai saran. 
Hasil Uji coba Lapangan

Uji coba dilakukan pada peserta didik kelas IV SDN 2 Selong tanggal 19 Agustus 2019 dengan jumlah 30 siswa. Berdasarkan hasil penilaian angket respon siswa dapat diketahui bahwa penilaian produk berupa media pembelajaran berada pada rentang skor $X>42,06$ dengan rerata skor 42,13 dengan kategori "SANGAT BAIK". hal ini menunjukkan bahwa respon siswa terhadap media komik sangat baik, dan layak digunakan dalam proses pembelajaran.

\section{Pembahasan}

\section{Tahap Pengembangan Media Komik}

Proses pengembangan media komik ini dilakukan secara bertahap dengan mengacu pada model 4D yang kemudian disederhanakan menjadi 3 tahapan berdasarkan kebutuhan pengembangan yaitu 1) Define (Pendefinisisan); 2) Design (Perancangan); 3) Development (Pengembangan). Media komik ini diperuntukkan kepada siswa Kelas IV SDN 2 Selong, pada mata pelajaran IPS yang ada dalam buku tema 7 sub tema 2 indahnya keragaman budaya di Indonesia.

Tahap pertama yang dilakukan peneliti dalam proses pengembangan media komik ini yaitu pendefinisian. Tahap ini sesuai dengan tahapan pada model yang digunakan, diamana pada tahap ini peneliti menganalisis kebutuhan, dengan tujuan untuk mengetahui permasalahan yang terdapat dalam proses pembelajaran, baik itu yang dihadapi oleh guru maupun siswa.

Selanjutnya dilakukan analisis peserta didik. Hasil analisis ini menunjukkan bahwa siswa kelas IV SDN 2 Selong memiliki kecendrungan belajar yang beragam namun ada satu hal yang dapat menyamakannya yaitu kecendrungan menyukai buku bacaan yang memiliki gambar dan warna yang menarik, seperti komik.

Analisis selanjutnya yaitu analisis materi dimana materi yang ditetapkan untuk mengembangkan media komik ini adalah materi yang ada pada mata peajaran IPS tentang "Indahnya Keragaman Budaya di Indonesia" yang terdapat pada tema 7 subtema 2.

Tahap kedua yaitu perancangan. Rancangan awal media komik ini dirancang dengan menggunakan aplikasi Adobe Illustrator dan Adobe Photoshop. Tahap ketiga yaitu pengembangan. Tahap ini bertujuan untuk menghasilkan rancangan awal media 
komik atau prototype 1 yang dikembangkan oleh peneliti, kemudian divalidasi oleh dua orang validator ahli yaitu ahli desain dan ahli materi, yang merupakan dosen Universitas Hamzanwadi dan Guru kelas IV SDN 2 Selong, dengan memberikan penilaian pada lembar validasi. Hasil revisi yang telah dinyatakan valid, dan dapat diuji cobakan.

\section{Tingkat Kevalidan Media Komik}

Media komik dikatakan valid karena telah memenuhi dua aspek yaitu yang pertama aspek isi yang berarti bahwa media komik yang dikembangkan berdasarkan model pengembangan yang dijadikan pedoman yang dalam penelitian ini mengacu pada model 4D. Aspek yang kedua yaitu aspek konstruk yang berarti bahwa ada keterkaiatan komponen media komik dengan tuntutan kurikulum yang diterapkan. Hasil penilaian dari validator kemudian dianalisis menggunakan teknik analisis data kevalidan sehingga diperoleh skor rata-rata hasil penilaian yang menyatakan media komik berada pada kategori valid. Begitu pula dengan hasil uji coba pada siswa kelas IV SDN 2 Selong. Kategori ditentukan berdasarkan kriteria kevalidan yang telah ditetapkan sebelumnya, dengan menggunakan skala lima, dimana data mentah yang diperoleh kemudian dikonversikan kedalam rumus konversi data kualitatif ke data kuantitiatif skala lima. Yang menunjukkan bahwa respon peserta didik terhadap media komik berada pada kategori "Sangat Baik".

\section{SIMPULAN}

Berdasrkan hasil peneilitian dari pengembangan komik sebagai media pembelajaran IPS kelas IV SDN 2 Selong, diperoleh kesimpulan yaitu telah dihasilkan media komik untuk siswa kelas IV SDN 2 Selong pada mata pelajaran IPS yang terdapat pada buku tematik, tema 7 subtema 2 Indahnya kreagaman budaya negeriku. Proses pengembangan media komik mengacu pada model 4D yang disederhanakan menjadi 3 tahapan berdasarkan keterbatasan pengembangan. Media komik yang dikembangkan telah dinilai valid berdasarkan hasil penilaian oleh dua orang validator ahli yaitu ahli desain dan ahli materi. Hasil validasi pertama oleh ahli desain diperoleh skor 47 yang berada pada rentang skor $39<\mathrm{X} \leq 51$, dengan kategori "Cukup". Hasil validasi ke dua oleh ahli desain diperoleh skor 57, yang terdapat pada rentang skor 51 < X 63 dengan kategori "Baik". Hasil validasi ahli materi memperoleh skor 60 , yang berada pada rentang skor $51<\mathrm{X} 63$, dengan 
kategori "Baik". Hasil uji coba lapangan memperoleh rata-rata skor 42,13 yang berada pada rentang $X>42,06$, dengan kategori "Sangat Baik". Hal ini menunjukkan bahwa media komik layak digunakan sebagai media pembelajaran.

\section{DAFTAR PUSTAKA}

Nick Soedarso. (2015). Komik Karya Sastra Bergambar. Jurnal Humaniora. Volume 06, Nomor 4, hal. 496-506.

Nurgiyantoro, Burhan.(2013).Sastra Anak Pengantar Pemahaman Dunia Anak. Yogyakarta: Gajah Mada University Press.

Sadiman, dkk.(2012).Media Pendidikan Pengertian Pengembangan dan Pemanfaatan. Jakarta: PT Rajagrafindo Persada.

Sugiyono.(2016).Metode Penelitian dan pengembangan (Reasearch and Development $R \& D)$ ). Bandung: Alfabeta.

Susanto, Ahmad.(2014).Pengembangan Pembelajaran IPS di Sekolah Dasar. Jakarta: Prenademia Group.

Widyoko, Eka, P.(2017).Evaluasi Program Pembelajran Panduan Praktis Bagi Pendidik dan Calon Pendidik. Yogyakarta: Pustaka Pelajar. 